\title{
The art and architecture of Chora Monastery in comparison with its East European and Italian contemporaries
}

\author{
Z. Atas \\ Department of Architecture, Istanbul Technical University, Turkey
}

\begin{abstract}
This research aims to analyze both the architecture and art of today's Chora Museum, named Chora Monastery and Chora Mosque chronologically, in comparison with its East European and Italian contemporaries, within the social, cultural and political environment of the Byzantine Empire and the context of Byzantine art developed until and through the 14th century when the spectacular and cinematographic mosaic scenes and frescos covering the vaults and dome of the building, illustrating the life cycles of both the Virgin Mary and Jesus Christ with an unconventional use of perspective, were built and painted.

The monastery, named Chora meaning "country", "land" or "in the country" in Greek, referring to its location, was built originally in the 12th century right outside the city walls of Constantinople. The architecture of the building is a combination of different parts built at different time periods in history; the 12th century, from which only the naos part remained; the 14th century, Palaeologans' reign which is referred to as the brightest time of Byzantine art, and when the naos dome, the north annex, the narthexes, the parekklesion, and a belfry were built together with all the brilliant marble decoration, mosaics and frescoes; and finally the15th century Ottoman era, in which, being turned into a mosque, a mihrab and a minaret were added to the building, together with the plaster covering the mosaics and frescos, which has actually preserved them up to this day.

Kariye Museum, as of today, offers different readings of all this juxtaposition at one and the same time and space. The strong storm of the imagery and the extraordinary way the life cycles of the Virgin Mary and Jesus Christ were represented, as the ways the cities, buildings, people and their acts were illustrated, comparing to the Byzantine, East European and Italian religious art of
\end{abstract}


the era, makes it possible to say, has affected a wide area, including both the Byzantine Orthodox Church jurisdiction areas and even Italy as far as mannerisms are concerned.

Keywords: Chora Monastery, Byzantine art, mosaic.

\section{Introduction}

Kariye Museum, as of today, consistent with its collection of names, which chronologically are Chora Monastery and Kariye Mosque, offers a juxtaposition of different levels of time-space unity with its great collection of mosaics and frescos depicting the scenes from the life cycles of Jesus Christ and the Virgin Mary, and the extraordinary way those are represented together with its eclectic space corresponding to the artwork it embodies.

The art of the mosaics and frescos, especially the use of perspective challenging the classical perspective together with the way figures are drawn, forms one of the best examples of $14^{\text {th }}$ century Byzantine art which effects Balkans, Georgia and Russia, as the official art of the Byzantine Orthodox Church in its jurisdiction areas [1].

The art of the Kariye mosaics and frescoes nourished by the political environment of the $14^{\text {th }}$ century Byzantine Empire is discussed, in comparison with Italian and Balkan art following a brief history of the building and an analysis of the stories, the way they are represented and space-story correspondence creating different time-space unity at one and the same time and space.

\section{Knowing the building}

Kariye building is a complex with different parts of different times forming a whole together. The plan below shows its parts with their locations within the whole.

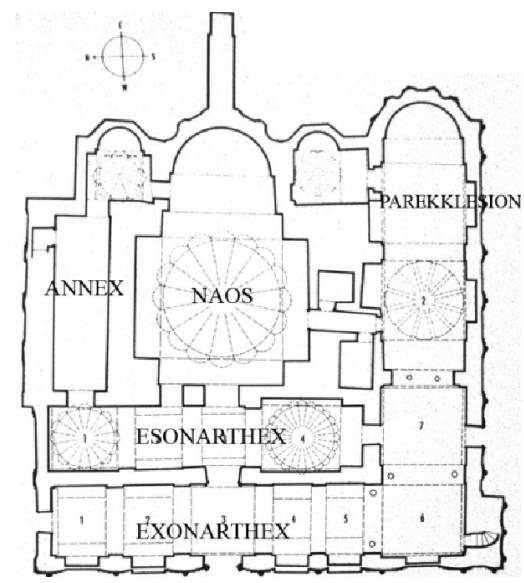

Figure 1: Kariye Museum, parts [1]. 
The main part is the naos in the center of the building where the church services occur. It is the main worship area. The naos has a windowed dome in the center and an apse on the east wall.

At the north of naos lays the annex with its two floors, the second floor overlooking naos with a small window. It most probably contained the monastery library.

To the west side, there are two narthexes from which the entry occurs; the exonarthex is the outer one, the esonarthex is the inner one. The narthexes both house spectacular mosaic scenes. While the life cycle of the Virgin Mary is in the inner narthex, Jesus Christ's life cycle is in the outer narthex.

At the south, the parekklesion which functioned as a funeral chapel exists. The parekklesion preserves frescoes including the Last Judgment.

\section{A brief history of the building}

The word Chora means in Greek "country", "land" or "in the country" as the monastery was built outside the city walls of Constantinople, by Edirnekapi. The earliest findings are the substructures forming a flat platform against the slope for the main building date to the $6^{\text {th }}$ century, in Emperor Justinian's reign.

Only the naos of today's building is from the early $12^{\text {th }}$ century, Komnenian Period, probably built by the Crown Prince Isaak Komnenos as his picture still states in one of the mosaics of the Chora [1].

Having being damaged during the Latin invasion of Constantinople between 1204 and 1261, some minor restoration and renovation was undertaken during the late $13^{\text {th }}$ and early $14^{\text {th }}$ centuries probably by Melanie the nun, one of the daughters of the Emperor. She was also pictured in the same mosaic, Deesis, together with the Crown Prince Isaak Komnenos [1].

The Chora had the main restoration and renovation work starting from 1315 or 1316. It was Theodore Metochites, a statesman and a scholar, who undertook the work. He was the first non-imperial to be the founder (ktetor) of an imperial monastery and the richest man in Byzantium after the Emperor. It was then the Palaeologans' time to reign and the brightest time for Byzantine art [1].

The naos dome, the north annex, the narthexes, the parekklesion, and a belfry were built together with all the brilliant marble decoration, mosaics and frescoes. The work was completed in 1321 [1].

Metochites' mosaic is still present at the monastery, right over the entrance door to the naos, as the donor, offering the monastery to Christ. He died and was buried within the parekklesion as a monastic person with the taken monastic name, Theoleplos in 1332 [1].

During the Ottoman period, between 1495 and 1511 the Chora was turned into a mosque taking the Arabic name Kariye which means the same as chora. Some of the illustrations were plastered which actually preserved them very well. A mihrab to the southeast on the wall of the apse and a minaret in place of the belfry was built [1].

In 1945 Kariye Camii was turned into a museum. 


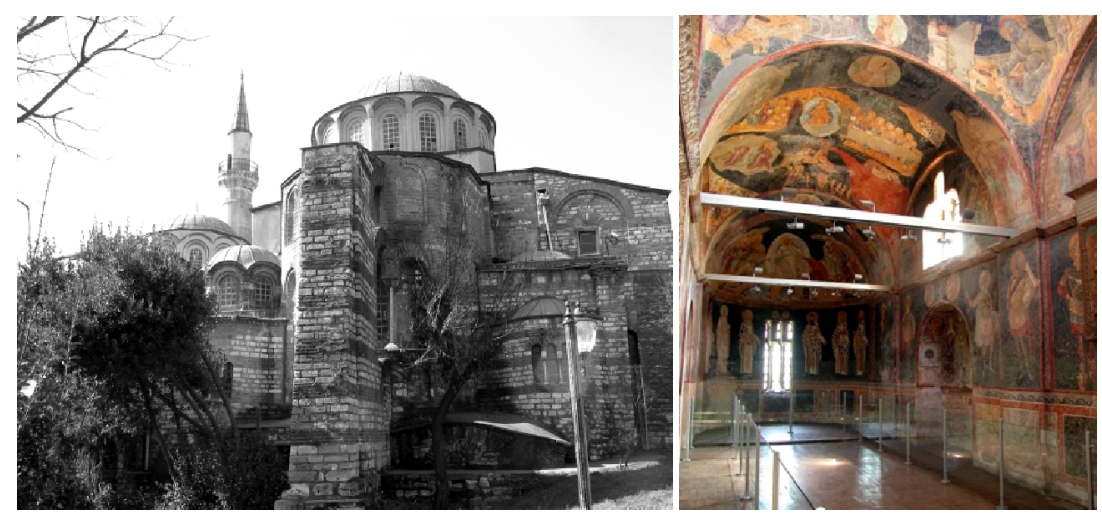

Figure 2: $\quad$ Kariye Museum [1].

The cleaning and restoration of mosaics and frescoes and the building itself was undertaken during the 1950s by the Byzantine Institute of America and Dumbarton Oaks Field Committee [1].

\section{The art and the corresponding space}

With its space organization together with the decoration corresponding to the function of space it belonged to (liturgy), Chora Monastery, Kariye Camii or Kariye Museum offers different levels of time-space readings at one and the same time.

Chora Monastery narthexes and the parekklesion offer a great collection of mosaics and frescoes. The inner narthex houses the life cycle of the Virgin Mary together with the miracles of Christ while the outer narthex contains the narrative images from the life cycle of Christ.

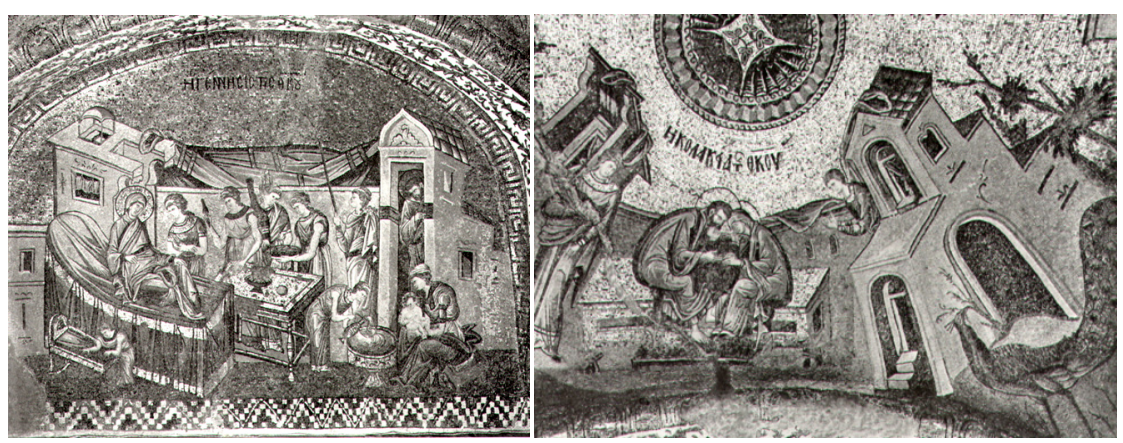

Figure 3: The birth of Mary (left), Mary caressed by her parents (right) [2].

A cinematographic space is created by the mosaics following each other story wise. It is probably what makes Chora special and different from any other example of spaces of its kind. The reason for that would first of all be the dense 
use of narrative images within the building and then, the strong and almost mannerist expressions of the narrative imagery together with the extraordinary representations of space that makes it easy to get caught within the narratives.

The weirdness of the images to the educated mind makes one lose oneself through the spaces and the narrative of the story, within other time-space unity.

The representations within the space and their relation to the program of that one and the same space, liturgy, strengthen that other time-space unity. Parekklesion, the funeral chapel, for instance, exemplifies the liturgy, containing scenes corresponding to the idea of death and resurrection like The Last Judgment, The Hymnographers, Anastasis, Jacob's Ladder, with its strong world of imagery almost creating one's transfiguration in the middle of a funeral ritual.

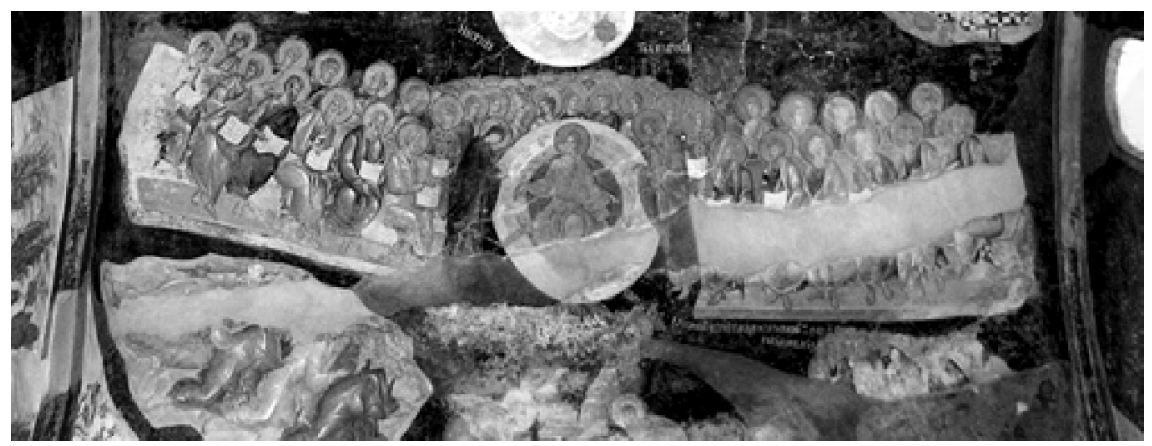

Figure 4: The Last Judgment.

The Last Judgment which is situated at the east bay of the parekklesion shows "Christ's triumph over death and redemption of the righteous". There exist four tombs in the parekklesion and all the dead that were put into the tombs, seated facing The Last Judgment scene, waiting for the inevitable.

The hymnographers are seated on the pendentives of the dome, writing. These were writing poems "honoring the Virgin". The northeast pendentive shows John of Damascus, a famous writer and theologian from the $18^{\text {th }}$ century. In the southwest pendentive a ninth century hymnographer Joseph stays. Another ninth century poet who was also a monk at the Chora is shown in the northwest pendentive while the southeast pendentive houses the poet Kosmas, a student of John of Damascus. The space under the dome of the parekklesion was where the dead laid for the ritual of his family seeing him and hymns were sung upon him during this ritual. The frescoes of the hymnographers illustrated in the pendentives of the dome correspond to the funerary ritual of the time [3].

Parekklesion and the Mosaic Deesis also offer an opportunity to experience different times, the past, the present and the future at one and the same moment.

Parekklesion contains illustrated stories from the Old Testament, The New Testament and the scenes The Last Judgment as mentioned above. The Old Testament features Mary. The most striking scene from the Old Testament is the Jacob's Ladder scene, situated right at the tomb of Metochites, on the right hand side of the dead person lying under the dome during the funeral ritual. Jacob 


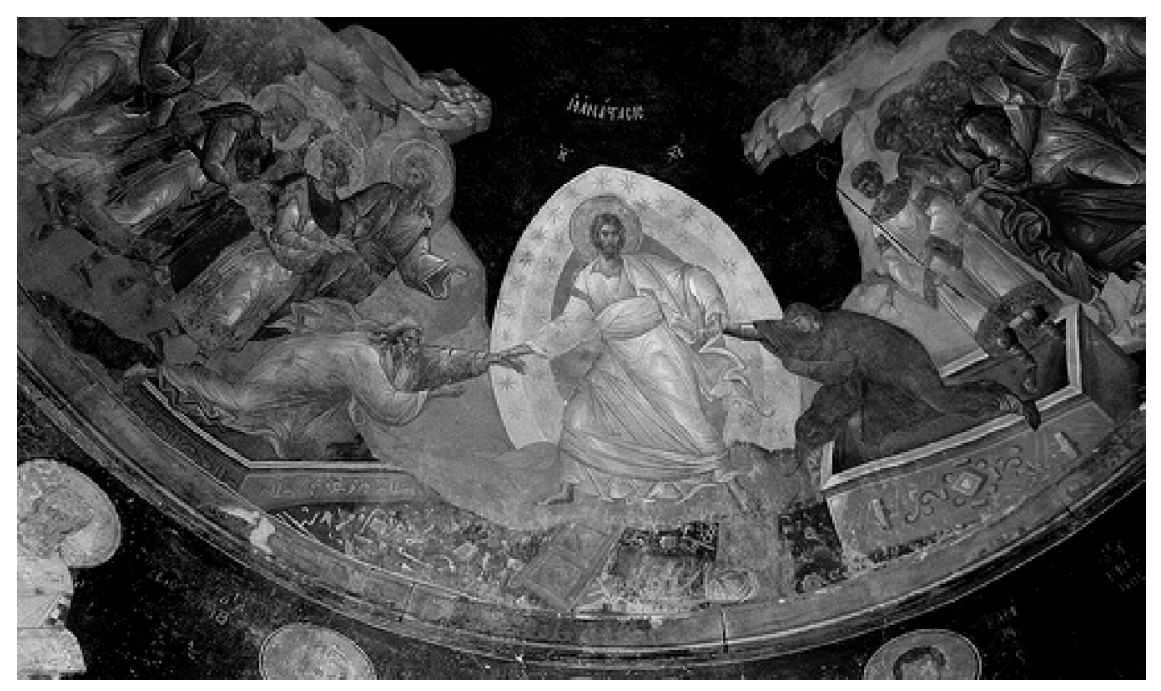

Figure 5: Anastasis.

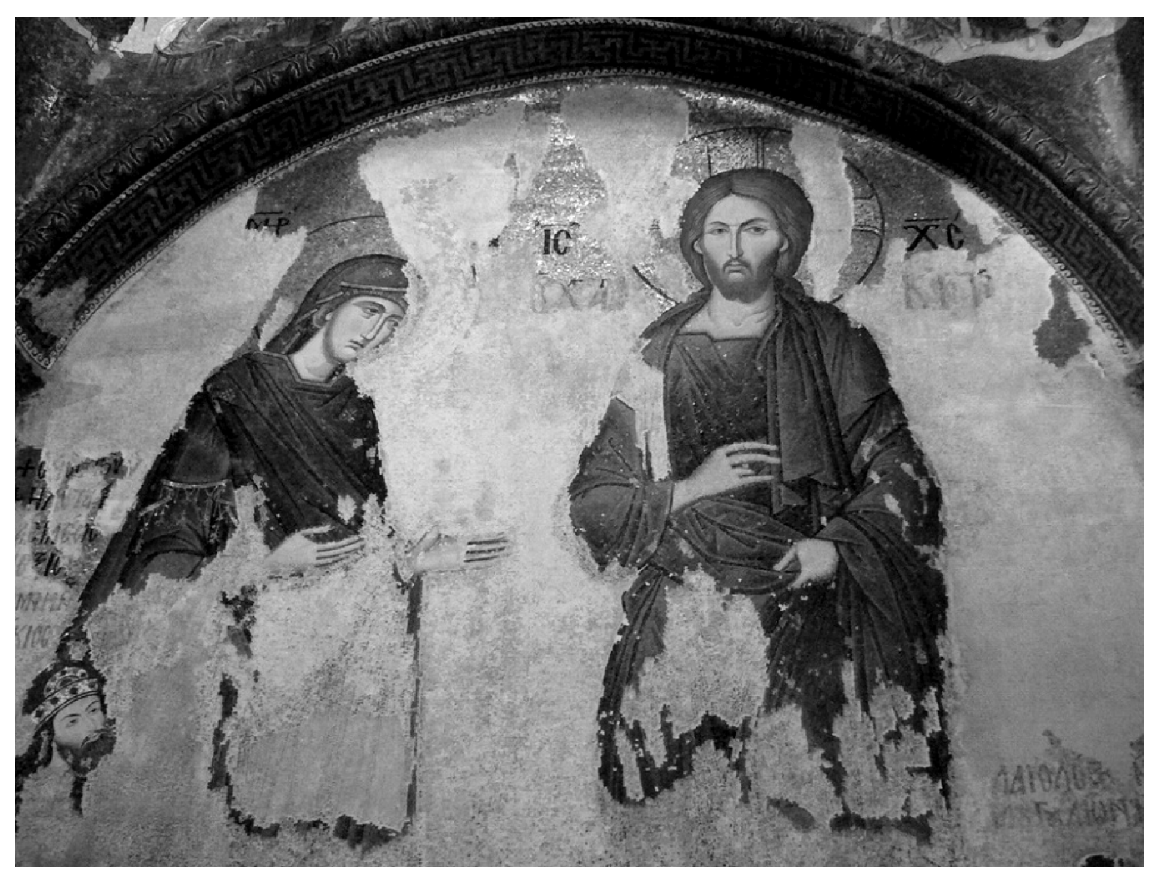

Figure 6: Deesis mosaic.

dreams of a ladder leading to Heaven upon which the Virgin Mary together with baby Jesus appears as the survivor of humanity. 
While The Old Testament and The New Testament featuring Christ's Miracles like Raising (giving life to the dead) represent the past, The Last Judgment and the Adam and Eve's resurrection scene (Anastasis) where Christ pulls Adam and Eve from Hell represent the inevitable future of humanity.

Deesis Mosaic offers another time superimposition. It represents Virgin Mary together with Christ accompanied by two little figures, one of Isaak Komnenos' and the other of Melanie the nun's. These characters were mentioned in the history part above that they were the two donors to the monastery in different centuries.

An addition would be the different functioning of the building throughout the centuries taking three different names correspondingly and carrying traces of each one. The names Chora Monastery, Kariye Camii and Kariye Museum corresponding to different periods of the building juxtapose at present time with remainders of all.

\section{A comparison of $14^{\text {th }}$ century Byzantine art with Balkan and Italian art through the artwork in Kariye Museum}

Any change in the political scene and in religious power, especially in the case of the Byzantine Empire, as the Orthodox Church is the power, affected the social and cultural life and state of art in the empire.

Byzantine art is said to have lived its brightest time during the $14^{\text {th }}$ century as the political and religious characters were totally supportive of revolutionary, new art at the same time $[1,4]$.

The Palaeologans were on the throne and the church was dominated by Barlaam, a religious thinker, who had revolutionary thoughts, such as separating the examination of the material world from the spiritual one [4].

Byzantine art was revolutionary during the $14^{\text {th }}$ century after having passed the period of iconoclasm, in the late $8^{\text {th }}$ and early 9 th centuries, when all the icons and illustrations within the religious institutions were broken, and the conservative Komnenian Period which limited the artists with the mandatory use of traditional Byzantine iconography together with simplified figures from the antique period in the religious illustrations [4]. This mandatory use of figures from antiquity on the other hand and in contrast to what Italians did at that time is the only reason that the precise antique knowledge could be preserved for centuries and presented back to Italy especially in the $13^{\text {th }}$ and $14^{\text {th }}$ centuries [5].

One of the most deterministic characteristics of the Palaeologan period, 12611340 , is the admiration of antiquity. Together with the secularity of the church, there happened a return, and anything from the Antique Period had been reexamined and tried to be reunderstood. Observation of the material world reappeared in art $[4,5]$.

The artists were not rationalizing the antique thought though, to merge with their own science and methods as the Italians did but exploring it to enrich their traditional way of doing things. This is the fundamental difference of Byzantine art from the Italian art of the era; the rediscovery of antiquity in Italy, its reinterpretation and progressive internalization within the art happened in 
parallel with the internalization of antique science and methods [4]. There is no such internalization in Byzantine art, on the contrary; although explored thoroughly, antique was kept as antique. Artists used their observations of the world together with the figures only from antiquity and merged them into the medieval religious scenes they had been working on. They designed movement, more dynamic figures compared to the ice-cold medieval ones.
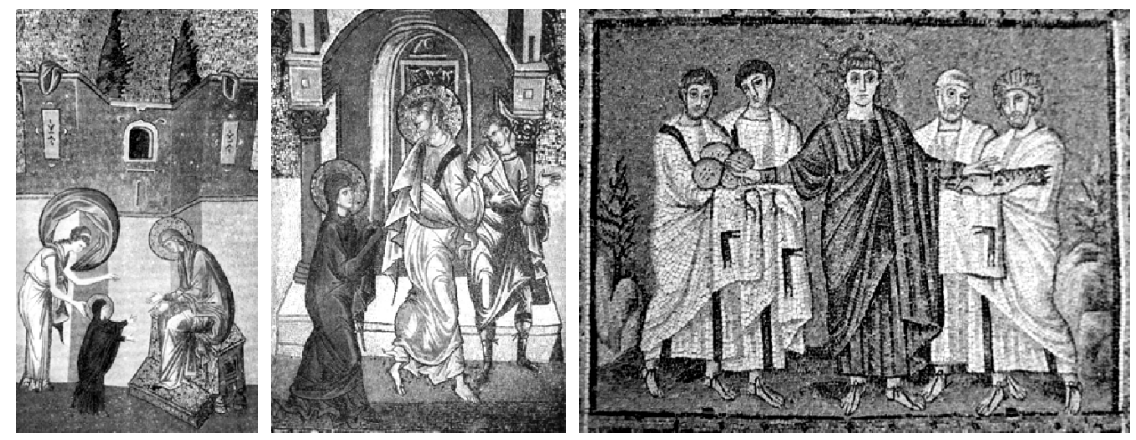

Figure 7: Scenes from Kariye (left), the bread and fish miracle A.C. 520 (right) $[2,6]$.

This mentality keeps Byzantine art in a state of rough transformation, where certain ideas - figures belonging to certain periods - could be identified within a thousand years of art tradition but still offering a new whole, that is Palaeologan art [4].
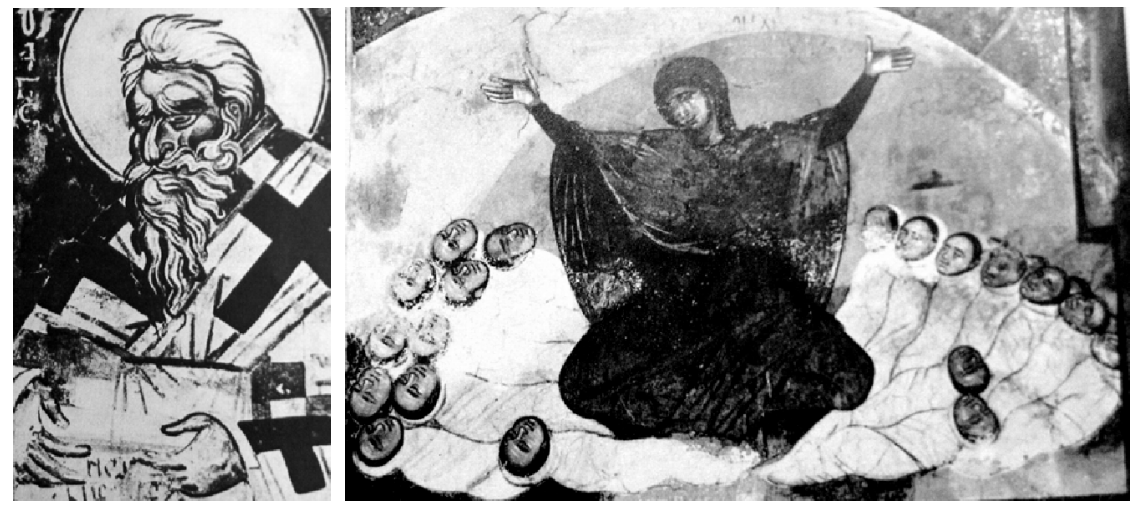

Figure 8: Saint Blaise (left), Rachel crying for her children's death (right)[5].

Being in the jurisdiction area of the Byzantine Orthodox Church, Balkan art of the era demonstrates similar characteristics to Byzantine art; details depending on material world observation penetrating within classical iconography. Two scenes from the Marcov Monastery from the mid $14^{\text {th }}$ century, "Saint Blaise" and "Rachel crying for her children's death" demonstrates the use of both 
iconography and the artist's personal observations at the same time; with the detailed face of the saint, especially the hair and nose expressions depending on the personal observation at the former, and the abstract iconographic depiction of the latter [5].

The following are a couple of example scenes discussing $14^{\text {th }}$ century artwork (frescoes and mosaics) having the same name, corresponding to the same religious-historical events from different religious buildings, Kariye Museum from Istanbul, Padova Scrovegni Chapelle from Italy, Ohrid, Decani and Gracanica Churches from the Balkans. Similarities and differences can be seen directly when three different depictions of the same story are put together.

First of all, for the "Anna and Joachim meet" scene; Protoevangelium says "and Anna stood by the gate...", whence Latin Pseudo Matthew says "...go to the gate which is called Golden" [3].
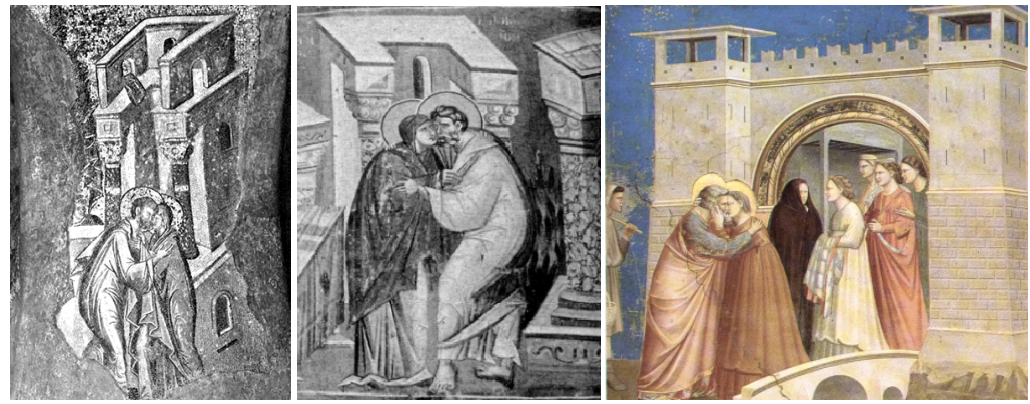

Figure 9: Scenes from Kariye, Ohrid and Scrovegni from left to right $[2,7,8]$.

While, in Scrovegni, Anna meets Joachim in front of a golden gate, in Kariye and Ohrid mosaics, the meeting happens in front of their house. The depiction of "houses" in Kariye and Ohrid are very similar with the column headings and window details together with the characters and the way they demonstrate their emotions.

Underwood mentions picturing the Golden Gate in Scrovegni, Giotto might have been affected from the monuments he had seen while staying in Rimini before he moved to Padova [3].
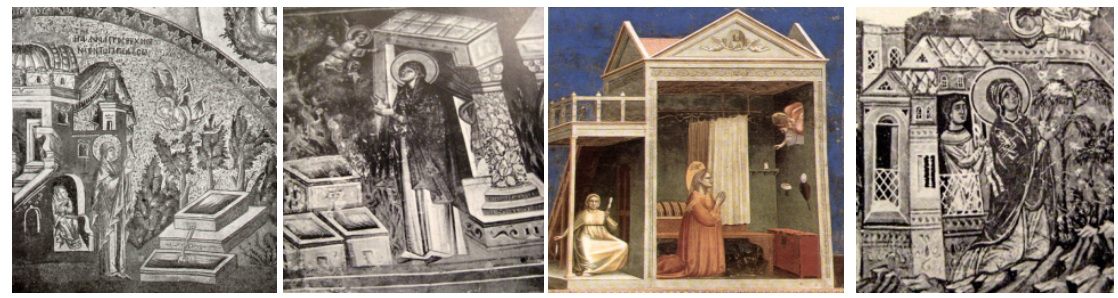

Figure 10: Scenes from kariye, ohrid, scrovegni and pelendri from left to right $[2,7,8]$. 

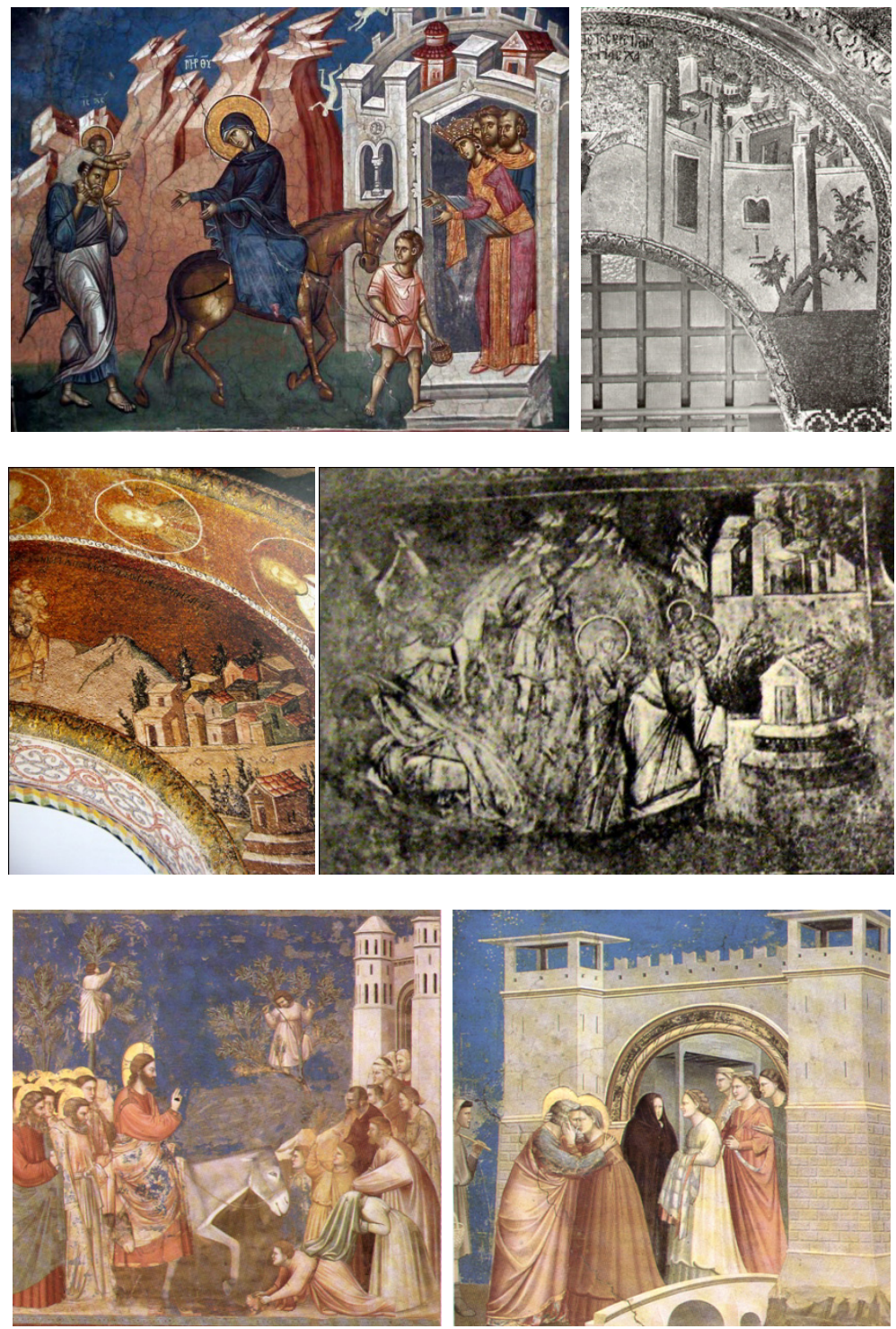

Figure 11: "Fleeing to Egypt" Decani, "going to Jerusalem for passover" Kariye, "Return from Egypt" Kariye, "return from Egypt" St. Nicolas Romania, Scrovegni, "Anna and Joachim meet" Scrovegni (left to right) [2, 7, 9].

Annunciation to Anna Scene is another example.

Annunciation takes place outside, in the garden except for the fresco in Scrovegni. A fountain is a common element in Kariye and Ohrid. 
The use of renaissance perspective is another point of distinction between the scenes. There is an obvious proficiency in the use of classical perspective in the Scrovegni one compared to the rest which have certain distortions to the buildings and characters. Underwood mentions this distortion could be an expression of topography and the viewer's location according to the scene illustrated. So the artist had probably drawn the fountain, in the first mosaic for instance, from above and the house from below [3].

The detailed depictions of curtain rode, the stairs, the red chest or the yarn spinning tool in Scrovegni are expressions of strong observation.

Finally the depictions for city space is compared below.

City space depictions for Egypt in Decani and Jerusalem in Kariye resemble each other so much that it is worth mentioning them here. The bastions on the city walls, even the window depictions are almost the same. In addition to those, the domed building repeats, interestingly in both scenes.

The building outside the city walls in the Nazareth city depictions of the "return from Egypt" scenes in St. Nicolas Church and Kariye Museum are drawn astonishingly, almost the same.

Unlike the rest, there is no depiction for the inner city in the frescos of Scrovegni. The city walls of Jerusalem are seen together with the gate and the bridge.

\section{Conclusion}

The $14^{\text {th }}$ century had been a period when artists restarted to explore and observe their surroundings and insert those real-life observations into abstract, almost expessionless religious representations. Palaeologan art is accepted as the brightest level a-thousand-year Byzantine art tradition reached, enriched by the figures from antiquity and expressions of the artists' personal observations. It had spread out of the borders of the empire to the jurisdiction areas of the Byzantine Orthodox Church, especially to the Balkans and Russia.

Chora exemplifies the most interesting art of its time considering the unusual and almost mannerist expressions of space together with the figures within the story. As a building today, together with the artwork, corresponding space and eclectic architecture, Kariye Museum acts as an embodiment of different timespace experiences at one and the same place.

\section{References}

[1] Ousterhout, R., The Art of The Kariye Camii, Scala: İstanbul 2002.

[2] Underwood, P.A., Kariye Djami, 1, 2 vols. Routledge \& Kegen Paul Ltd.: London 1967.

[3] Demus, O., The Style of the Kariye Djami and Its Place in the Development of Palaeologan Art, in Underwood, P.A., The Kariye Djami, 4 vols. Routledge \& Kegen Paul Ltd.: London 1975. 
[4] Grabar A., The Artistic Climate in Byzantium During the Palaeologan Period, in Underwood, P.A., The Kariye Djami, 4 vols. Routledge \& Kegen Paul Ltd.: London 1975.

[5] Rice, D.T. , Art of the Byzantine Era, Thames and Hudson: London 1985

[6] Gombrich, E. H., History of Art, Remzi Kitabevi: İstanbul 1997

[7] ICONS OF MACEDONIA, www.soros.org.mk/konkurs/019/eng/cent14.htm

[8] Padova, La Capelli degli Scrovegni, Giotto, Edizioni Storti: Venedik 198688

[9] DECANI MONASTERY http://www.kosovo.net/dec_frescoes.html. 